\title{
EKSISTENSI PERJANJIAN ASEAN-CHINA FREE TRADE AREA (ACFTA) DAN DAMPAKNYA BAGI PERLINDUNGAN USAHA MIKRO KECIL MENENGAH (UMKM)
}

\author{
Ari Ratna Kurniastuti \\ Peneliti di Lembaga Penelitian SEMERU Jakarta \\ Email: ariratna.kurniastuti@gmail.com
}

\begin{abstract}
Journal writing is about the existence of Agreement of the ASEAN-China Free Trade Area (ACFTA) and its impact on the legal protection of micro small and medium enterprises (SMEs). It is motivated by the ACFTA agreement that went into effect on January 1, 2010 many local industries including the SMEs gain a tremendous impact, ranging from reduced turnover, to anyone out of business. Seeing as it is a phenomenon that needs to be assessed on the first position of the ACFTA agreement in the Indonesian legal system relating to the case of a legal conflict with national legislation that protects SMEs. The second study is about the ideal form of legal protection for SMEs from the impact of the ACFTA agreement.
\end{abstract}

Key words: legal protection, the micro, small and medium enterprises (smes), treaty of asean china free trade area (ACFTA)

\begin{abstract}
Abstrak
Penulisan jurnal ini membahas tentang eksistensi Perjanjian ASEAN-China Free Trade Area (ACFTA) dan dampaknya bagi perlindungan hukum Usaha Mikro Kecil Menengah (UMKM). Hal ini dilatarbelakangi dengan adanya perjanjian ACFTA yang mulai berlaku pada 1 Januari 2010, dimana banyak industri lokal termasuk di dalamnya adalah UMKM mendapatkan dampak yang luar biasa, mulai dari penurunan omset, sampai ada yang gulung tikar. Melihat fenomena demikian maka perlu dikaji mengenai pertama kedudukan Perjanjian ACFTA dalam sistem hukum Indonesia berkaitan dengan terjadinya konflik hukum dengan peraturan perundang-undangan nasional yang melindungi UMKM. Kajian kedua adalah tentang bentuk perlindungan hukum yang ideal terhadap UMKM dari dampak adanya perjanjian ACFTA.
\end{abstract}

Kata kunci: perlindungan hukum, usaha mikro kecil menengah (UMKM), perjanjian Asean-China Free Trade Area (ACFTA)

\section{Latar Belakang}

Perdagangan adalah fitrah manusia, ini dilakukan untuk memenuhi kebutuhan.

Perdagangan atau perniagaan adalah kegiatan tukar menukar barang atau jasa atau keduanya. ${ }^{1}$ Sebelum muncul sistem Negara pada abad ke 19 sudah ada perdagangan antar suku bangsa, misalnya Marcopolo dari Venezia, sekarang lebih dikenal dengan Italia dengan Jalur Sutranya. Saat itu

1 Wikipedia, Perdagangan, http://id.wikipedia.org/wiki/Perdagangan, diakses 20 Mei 2012 pukul 12.05 WIB. 
perdagangan sangat bebas, suku bangsa satu dapat membawa barangnya ke suku bangsa lain untuk dijual tanpa dibatasi dengan aturan Negara.

Di abad 19 sistem di dunia berubah yaitu mulai bermunculan negara-negara yang mendahulukan kepentingan politik, negara dengan rasa nasionalisme dan kebangsaan, sehingga sistem hukumnya melindungi kepentingan bangsanya terlebih dahulu termasuk dalam hal perdagangan. Pada era ini perdagangan antar negara sudah tidak sebebas era Marcopolo. Untuk dapat menjual barang dari Negara satu dengan yang lain ada aturan tentang dokumen atau bea masuk misalnya, sehingga kemudian istilah perdagangan berubah menjadi perdagangan internasional.

Kebangkitan nasionalisme dan kodifikasi pada abad ke-19 hukum dagang itu dimasukkan ke dalam undang-undang masing-masing negara. Ini menjadi bercampur dengan hukum nasional dan dengan demikian kehilangan karakter universalnya. Sebagai negara yang mengambil kontrol atas perdagangan internasional, hukum perdagangan nasional yang baru mengatur hubungan ekonomi dan perselisihan lintas batas yang diselesaikan dengan mengacu pada hukum internasional privat. $^{2}$

Perdagangan Internasional adalah kegiatan-kegiatan perniagaan dari suatu
Negara asal yang melintasi perbatasaan menuju suatu Negara tujuan yang dilakukan oleh perusahaan untuk melakukan perpindahan barang dan jasa, modal tenaga kerja, teknologi (pabrik) dan merek dagang. ${ }^{3}$ Perdagangan internasional melibatkan Negara-Negara dan lembaga-lembaga internasional baik secara global maupun regional yang mengacu pada ketentuan dan prinsip-prinsip hukum internasional yang disepakati dalam General Agreement on Tariffs and Trade-World Trade Organization (GATT-WTO Agreement). Negara yang mengikatkan diri menjadi anggota WTO maka tunduk pada prinsip-prinsip yang diatur dalam GATT. Walaupun demikian GATT ini juga memuat ketentuan-ketentuan untuk menyimpangi prinsip dalam GATT-WTO Agreement misalnya yang tercantum dalam artikel XXIV yaitu diperbolehkan adanya perjanjian regional antara dua negara atau lebih untuk mengurangi atau menghapuskan hambatan perdagangan di antara sesama anggota perjanjian regional tersebut, dengan tujuan meningkatkan perdagangan di kawasan tersebut.

ASEAN-China Free Trade Area (ACFTA) merupakan tindak lanjut dari kesepakatan antara negara-negara ASEAN dengan Republik Rakyat China mengenai Framework Agreement on Comprehensive Economic Co-operation between the

2 Ana Mercedes Lopez Rodriguez, Lex Mercatoria, School of Law, Departement of Private Law University of Aarhus, 2002.

3 Mohammad Sood, Hukum Perdagangan Internasional, Raja Grafindo Persada, Jakarta, 2011, hlm. 18. 
Association of South East Asian Nations and the People's Republic of China ("Framework Agreement"), yang ditandatangani di Phnom Penh, pada 4 Nopember 2004. ${ }^{4}$ Framework Agreement on Comprehensive Economic Co-operation between the Association of South East Asian Nations and the People's Republic of China yang selanjutnya disebut Perjanjian ACFTA berlaku sejak 1 Januari 2010. Dasar berlakunya perjanjian ini adalah Keputusan Presiden No. 48 Tahun 2004 tentang Pengesahan Framework Agreement On Comprehensive Economic Co-Operation Between The Association Of South East Asian Nations And The People's Republic Of China. ${ }^{5}$

\section{ACFTA menggunakan prinsip} perdagangan bebas. Perdagangan bebas tersebut didefinisikan sebagai tidak adanya hambatan perdagangan, yakni hambatan yang diterapkan pemerintah dalam perdagangan antar individual dan atau perusahaan yang berada di negara anggota perjanjian perdagangan bebas tersebut. ${ }^{6}$

Industri manufaktur yang mulai bangkit setelah Krisis Keuangan Global yang kemudian disingkat KKG mereda harus siap menghadapi tantangan baru yaitu Perjanjian ACFTA. Empat industri manufaktur yang paling terancam adalah tekstil, alas kaki, garmen, dan plat baja karena produk China pada sektor ini dari segi biaya produksi murah dan efisien sebab mendapat subsidi dari Pemerintah mereka sehingga harganya murah. Hal ini membahayakan dari sisi tenaga kerja di Indonesia karena keempat industri tersebut merupakan sektor padat karya yang menyerap banyak tenaga kerja. ${ }^{7}$

Kondisi sebagaimana diuraikan di atas tentu saja memberikan dampak kepada perekonomian Indonesia dan industri lokal yang ada di Indonesia, salah satunya UMKM. Dalam pembangunan ekonomi Indonesia UMKM dianggap sektor yang mempunyai peranan penting. Sebagian besar jumlah penduduk Indonesia yang berpendidikan rendah kegiatan usaha yang dapat dilakukan adalah di usaha kecil baik sektor tradisional maupun modern.

Peranan UMKM menjadi bagian yang diutamakan dalam setiap perencanaan tahapan pembangunan yang dikelola Kementerian Perindustrian dan Perdagangan serta Kementerian Koperasi dan UKM. Akan tetapi usaha pengembangan yang dilakukan hasilnya belum memuaskan karena pada kenyataannya kemajuan UMKM sangat kecil dibandingan kemajuan yang dicapai oleh usaha besar. ${ }^{8}$ Kondisi ini juga dikarenakan kurangnya dukungan pasar.

4 Amrie Hakim, Dasar Hukum Pemberlakuan ACFTA, http://www.hukumonline.com/klinik/detail/ lt4b04bef2aa8ee/dasar-hukum-pemberlakuan- acfta, diakses 4 Desember 2012 pukul 12.05 WIB.

5 Ibid.

6 Ibnu Purna, dkk, ACFTA sebagai Tantangan Menuju Perekonomian yang Kompetitif, http://www.setneg. go.id/index.php?option=comcontent\&task=view\&id=4375\&Itemid=29, diakses 7 Mei 2012 pukul 13.00 WIB.

7 Surabaya Pagi, 28 Januari 2010, ACFTA Ancam Empat Industri Padat Karya, hlm. 10 kolom 4-5.

8 Abdul Rosid, Modul Manajemen UKM: UKM di Indonesia dan Peranan UKM, pksm.mercubuana.ac.id/ new/.../files.../31013-3-478126269633.doc, diakses 8 Mei 2012 pukul 13.00 WIB. 
Persetujuan Perjanjian ACFTA ini berakibat perdagangan Indonesia dengan Negara-Negara ASEAN dan China mengalami liberalisasi yang artinya mengurangi atau meniadakan hambatan perdagangan yang ada, sehingga tariff (bea masuk) dari produk Negara peserta ACFTA ini diturunkan atau bahkan ditiadakan. Berdasarkan penelitian World Trade Organization (WTO) tahun 1995, disimpulkan bahwa regionalisme perdagangan, termasuk free trade area, ternyata mendorong liberalisme perdagangan yang memberikan keuntungan pada NegaraNegara anggota oleh integrasi ekonomi yang terjadi. ${ }^{9}$

\section{Liberalisasi} perdagangan menguntungkan bagi Negara yang siap dan kuat industrinya sehingga bisa mengembangkan ekspor dengan cepat memanfaatkan minimalisasi hambatan perdagangan yang ada. Akan tetapi saat negara tersebut industri dan pelaku usahanya belum siap, maka yang ada negara tersebut hanya akan menjadi pasar penjualan bukan tempat produksi. Bagaimana dengan Indonesia, yang terlihat justru banyak produk China yang membanjiri sejumlah wilayah kota-kota besar sebagai dampak Perjanjian ACFTA, sehingga industri, terutama UMKM Indonesia dibuat kewalahan atas kondisi seperti ini.

Melihat kondisi tersebut diperlukan peran pemerintah melalui hukum yang dibuatnya untuk memberikan perlindungan hukum terhadap industri di dalam negeri, khususnya UMKM karena mereka mendapatkan dampak yang cukup besar dari adanya ACFTA ini, padahal di Indonesia UMKM berskala kecil yang dijalankan oleh perorangan atau pegawainya tidak sampai 100 orang, jumlahnya cukup banyak.

Penelitian ini menggunakan pendekatan historis (historical approach), pendekatan perundang-undangan (statute approach), pendekatan konseptual (conceptualapproach), dan pendekatan perjanjian (Treaty approach). Metode pengumpulan bahan hukum dibedakan atas bahan hukum primer dengan cara Studi Kepustakaan (library research). Analisis data dilakukan secara normatif kualitatif dengan teori untuk memberi arti dan menginterpretasikan setiap bahan hukum yang telah diolah dan kemudian diuraikan secara komprehensif dan mendalam sehingga dapat ditarik sebuah kesimpulan.

\section{Pembahasan}

\section{A. Kedudukan Perjanjian ACFTA dalam Sistem Hukum Indonesia}

Perjanjian ACFTA adalah salah satu bentuk perjanjian Free Trade Area (FTA) yang diperbolehkan menyimpangi Prinsip Most Favoured Nations (MFN) yang diatur dalam Artikel I GATT-WTO Agreement yang menentukan bahwa negara anggota

9 World Trade Organization, Trading into the Future : Introduction to the WTO. Beyond the Agreements. Regionalism-Friends or Rivals?, http://www.wto.org/english/ thewto_e/whatis_e /tif_e/bey_e.htm, diakses 8 Mei 2012 pukul 13.00 WIB. 
tidak boleh mendiskriminasikan negara anggota lainnya. Jika diberikan perlakuan khusus kepada suatu negara (misalnya dengan menurunkan bea masuk dari salah satu produknya), maka perlakuan yang sama juga harus diberikan kepada negara anggota lainnya. ${ }^{10}$ Namun penyimpangan ini dilegalkan dengan ketentuan yang tertuang pada Artikel XXIV GATT-WTO Agreement. Indonesia dan anggota ASEAN yang lain sebagai anggota WTO yang wajib tunduk pada semua ketentuan WTO juga diperkenankan untuk membuat perjanjian ACFTA sebagai penyimpangan prinsip WTO.

Perbaikan GATT-WTO Agreement idealnya terus dilakukan sebagaimana yang dilakukan sejak tahun 1947 dengan tujuan menyesuaikan dengan perkembangan perdagangan internasional. Setelah Uruguay Round terdapat perundingan lanjutan Putaran Doha. Putaran Doha ini belum menghasilkan apa-apa sampai sekarang, belum ada kesepakatan yang bisa didapat dari perundingan yang terakhir ini. Putaran Doha yang tak kunjung selesai padahal perkembangan perdagangan internasional memerlukan penyesuaian aturan yang kemudian memacu negara-negara anggota WTO membuat perjanjian perdagangan khusus di wilayah mereka.

Pasca gagalnya perundingan WTO yaitu Doha Round sejak tahun 2005 dan kembali gagal pada perundingan Jenewa pada Desember 2009, Pemerintah Indonesia "banting stir" dengan menandatangani FTA pada tingkat regional yaitu AFTA yang merupakan FTA antara negara ASEAN sendiri dan ASEAN dengan negara lain atau kawasan/region yang lain. ${ }^{11}$

Artikel XXIV GATT-WTO Agreement memperbolehkan adanya Customs Union dan Free Trade Area yang dibentuk dengan perjanjian internasional tertentu, dengan persyaratan tertentu yaitu dalam kawasan regional yang saling berdekatan dan tidak bertentangan dengan perjanjian yang dibuat setelah perang dunia kedua salah satunya GATT yang kemudian berubah menjadi GATT-WTO Agreement setelah WTO berdiri tahun 1995. GATT yang disusun tahun 1947 ini merupakan salah satu sarana mencegah meletusnya perang dunia lagi sebab negaranegara menyadari bahwa perdagangan yang menyebaban perang terjadi, maka dibuatlah aturan perdagangan internasional. ${ }^{12}$ Framework Agreement on

\section{Comprehensive Economic Co-operation} between the Association of South East Asian Nations and the People's Republic of China yang dalam tesis ini disebut sebagai Perjanjian ACFTA merupakan salah satu bentuk perjanjian internasional.

Jika WTO adalah forum kesepakatan perdagangan tingkat global, ditingkat regional

10 Artikel I General Agreement on Tariffs and Trade-World Trade Organization (GATT-WTO Agreement).

11 Daeng, dkk, Menggugat Perjanjian Kerjasama ASEAN-China, Global Justice Update, Tahun 7 Edisi Desember 2009, hlm. 77.

12 Pasal 3 artikel XXIV GATT-WTO Agreement. 
forum serupa untuk menetapkan kebijakan perdagangan juga ditetapkan. Ada beberapa perjanjian dengan area yang lebih kecil, misalnya The North American Free Trade Area (NAFTA) antara Amerika, Canada dan Mexico, tetapi juga ada kesepakatan yang bersifat regional seperti The Asia Pasific Economic Cooperation (APEC). ${ }^{13}$

Perjanjian internasional dirumuskan sebagai kata sepakat antara dua atau lebih subyek hukum internasional yaitu negara, tahta suci, kelompok pembebasan, organisasi internasional mengenai suatu obyek tertentu yang dirumuskan secara tertulis dan tunduk pada atau yang diatur oleh hukum internasional. ${ }^{14}$ Perjanjian ACFTA ini antara organisasi internasional yaitu ASEAN dengan Negara yaitu Republik Rakyat China (China) maka memenuhi pengertian perjanjian internasional di atas sehingga dapat dikatakan bahwa Perjanjian ACFTA ini adalah merupakan perjanjian internasional.

Perjanjian Internasional antara negara dengan organisasi internasional diatur dalam Vienna Convention on the Law of Treaties between States and International Organizations or between International Organizations (Done at Vienna on 21 March 1986) yang selanjutnya disebut Konvensi Wina 1986. Dalam konvensi ini cara pembuatan, mulai berlaku dan cara berlaku yaitu pengesahan juga diatur di dalamnya.

Berdasarkan Konvensi Wina 1986 pengesahan diartikan sebagai ratifikasi. Menurut Pasal 2 (1) b Konvensi Wina 1986 ratifikasi adalah pengesahan, tindakan konfirmasi formal, penerimaan, persetujuan dan aksesi. Terdapat perjanjian yang harus melalui ratifikasi untuk dapat dinyatakan berlaku dan ada pula yang berlaku tanpa melalui persyaratan ratifikasi biasanya muai berlaku pada saat penandatanganan, yang dalam perjanjian dirumuskan dengan tulisan: "The present agreement shall come into force on the date of its signing" "15. Tulisan tersebut apabila diterjemahkan dalam bahasa Indonesia artinya "Perjanjian ini mulai berlaku pada tanggal penandatanganan”, sehingga apabila perjanjian internasional mencantumkan ini maka sejak perjanjian tersebut ditandatangani maka langsung sah untuk berlaku di negara yang telah ditandatanganinya.

Indonesia memiliki undang-undang yang khusus mengatur tentang perjanjian internasional yaitu UU No. 24 Tahun 2000 Tentang Perjanjian Internasional yang di dalamnya juga mengatur mengenai pengesahan perjanjian Internasional ke dalam hukum Nasional. Pasal 3 UU No. 24 Tahun 2000 Tentang Perjanjian Internasional menyatakan: Pemerintah Republik Indonesia mengikatkan

13 Mansour Fakih, Runtuhnya Teori Pembangunan dan Globalisasi, Pustaka Pelajar, Yogyakarta, 2001, hlm. 212-213.

14 I Wayan Parthiana, Hukum Perjanjian Internasional (Bagian 1), Mandar Maju, Bandung, 2002, hlm. 13.

15 Damos Dumoli Agusman, Hukum Perjanjian Internasional (Kajian Teori dan Praktik Indonesia), Refika Aditama, Bandung, 2010, hlm. 69. 
diri pada perjanjian internasional melalui cara-cara sebagai berikut: (a) Penandatangan; (b) pengesahan; (c) pertukaran dokumen perjanjian/nota diplomatik; (d) cara-cara lain sebagaimana disepakati para pihak dalam perjanjian internasional.

Politik hukum ratifikasi yang dianut oleh suatu negara sangat dipengaruhi teori monisme dan dualisme. Teori monisme menyebutkan bahwa hukum internasional dan hukum nasional merupakan satu sistem hukum, sedangkan teori dualisme menyatakan bahwa hukum internasional dan hukum nasional merupakan dua sistem hukum yang terpisah Diantara kedua teori ini mana yang dianut oleh suatu negara maka politik hukum ratifikasinya akan mengikuti teori dasar ini. Kebijakan yang diambil Pemerintah dalam hal pengesahan perjanjian internasional, salah satunya adalah memilih politik hukum ratifikasi mana yang diterapkan pada pengesahan perjanjian internasional. Pada dasarnya politik hukum ratifikasi yaitu inkorporasi dan transformasi yang didasari pada teori monisme dan teori dualimse.

Teori monisme merupakan dasar adanya teori inkorporasi, ratifikasi secara inkorporasi adalah hukum internasional dapat diterapkan dalam hukum nasional secara otomatis tanpa adopsi khusus. Teori dualisme menjadi dasar dari teori transformasi, ratifikasi secara transformasi yaitu bahwa hukum internasional yang bersumber dari perjanjian internasional dapat diterapkan di dalam hukum nasional apabila sudah dijelmakan (ditransformasi) ke dalam hukum nasional, secara formal dan substantif, yaitu menempatkan perjanjian internasional yang telah disahkan (ratifikasi) sebagai bagian dari hukum nasional ini yang disebut dengan transformasi secara formal, dan mengharuskan adanya legislasi nasional tersendiri untuk mengimplementasikan perjanjian internasional yang telah disahkan, yang terakhir ini disebut sebagai transformasi secara substantif ${ }^{16}$

Indonesia sering menggunakan politik hukum ratifikasi transformasi formal yaitu UU atau Perpres pengesahannya hanya berisi menetapkan atau mengesahkan sebuah perjanjian internasional, sedangkan perjanjian internasionalnya menjadi lampiran pada UU atau Perpres ini. UU atau Perpres pengesahan ini tidak berisi transformasi material atau substantif dari perjanjian internasional yang disahkan. Transformasi formal ini bisa dikatakan sebagai inkorporasi diam-diam. ${ }^{17}$

Kelemahan dari transformasi formal adalah lampiran tidak dianggap peraturan perundang-undangan walaupun sudah dinyatakan sebagai lampiran yang tidak dapat dipisahkan terlebih lagi apabila tidak diterjemahkan dalam Bahasa Indonesia. Dengan demikian yang sering terjadi 
masyarakat tidak tahu bahwa perjanjian internasional yang menjadi lampiran dalam peraturan perundang-undangan merupakan suatu ketentuan yang mengikat dan harus dipatuhi, berbeda apabila perjanjian internasional ini ditransformasikan dalam suatu UU atau perpres dalam bentuk pasal per pasal.

Status Perjanjian ACFTA dalam sistem hukum Indonesia adalah berlaku dikarenakan beberapa alasan yang pertama perjanjian ini sudah melalui 3 tahapan yaitu perundingan, penandatanganan dan pengesahan. Yang kedua meskipun dalam Keppres pengesahannya hanya menjadikan Perjanjian ACFTA ini lampiran yang dinyatakan tidak dapat dipisahkan dan dianggap transformasi setengah hati atau pengakuan inkorporasi yang sembunyi-sembunyi tetapi tetap bisa dianggap berlaku karena memang kenyataannya Indonesia mengikuti transformasi, inkorporasi sekaligus.

Perjanjian ACFTA dinyatakan berlaku di Indonesia sehingga sudah menjadi 'undang-undang' bagi yang membuatnya termasuk Indonesia. Perjanjian ACFTA yang disahkan dengan Keppres ternyata memiliki dampak yang luas, industri lokal khususnya UMKM banyak yang gulung tikar atau mengalami penurunan omset sebagaimana telah diuraikan di latar belakang yang menjadi landasan penulis mengambil penelitian tesis tentang ini. Sektor pertanian termasuk perkebunan merupakan UMKM yang cukup besar jumlahnya di Indonesia, dan sektor ini merupakan salah satu yang terdampak dengan adanya perjanjian ACFTA ini. Kondisi ini memicu bermunculannya peraturan perundang-undangan yang tujuan memproteksi petani sebagai salah satu bentuk UMKM.

Gubernur Jawa Timur menerbitkan Peraturan Gubernur (Pergub) No 78 Tahun 2012 yang melarang impor seluruh produk hortikultura masuk ke wilayah Jawa Timur. Pergub ini ditandatangani tanggal 1 Maret 2012 bertujuan membentengi seluruh produk petani dari serbuan produk hortikultura impor. Tidak semua produk dilarang masuk, melainkan berlaku hanya bagi produk yang dimiliki oleh petani Jawa Timur, misalnya buah apel, jeruk, mangga, sayur, serta beberapa produk lainnya. Pelarangan impor produk holtikultura ini dalam kurun waktu sebulan sebelum panen dan dua bulan setelah panen. Karena itu, meski dilarang, jika impor tersebut masuk tidak saat terjadi panen raya, maka produk hortikultura tetap saja boleh masuk Jawa Timur ${ }^{18}$

Kondisi pertanian yang terpuruk dengan adanya Perjanjian ACFTA pada khususnya dan perdagangan bebas pada umumnya dan melihat pentingnya sektor ini untuk masyarakat maka akhirnya juga menggerakkan Menteri Pertanian dan Menteri Perdagangan mengeluarkan Peraturan Menteri (Permen)

18 Fatkhurrrohman Taufiq, 2 Maret 2012, Jawa Timur Larang Impor Hortikultura, Tempo Interaktif, http:// www.tempo.co/read/news/2012/03/02/180387611/Jawa-Timur-Larang-Impor- Hortikultura, diakses 7 Maret 2013 pukul 13.00 WIB. 
yang membatasi impor hortikultura dengan dikeluarkannya Permentan nomer 60 Tahun 2012 dan Permendag No 60/2012 soal impor hortikultura. Dalam lampiran Permendag No. 60/M-DAG/PER/9/2012 Tentang Perubahan Kedua Atas Peraturan Menteri Perdagangan Nomor 30/M-DAG/PER/5/2012 Tentang Ketentuan Impor Produk Hortikultura menyebutkan larangan terhadap 6 buah impor durian, nanas, melon, pisang, mangga dan pepaya masuk ke Indonesia. Selain keenam buah tersebut, pemerintah juga melarang impor 4 jenis sayur yaitu kubis, wortel, cabe, kentang, dan 3 Jenis bunga impor yaitu krisan, anggrek, heliconia.

Pembatasan ini jika dikaitkan dengan Perjanjian ACFTA ini juga melanggar, sebab Buah-buahan termasuk Early Harvest product (EHP) yang tariffnya sudah $0 \%$ sejak 1 Januari 2010 dan juga tidak ada pembatasan kuota. China belum pernah melaporkan untuk menuntut ini, tetapi pelaporan AS menunjukkan bahwa adanya peraturan yang demikian dapat memicu konflik dengan negara lain sebab mengindikasikan adanya pengingkaran terhadap perjanjian internasional. Pembatasan kuota atau kenaikan tariff diberbolehkan dengan syaratsyarat tertentu sesuai dengan Artikel XXIX GATT-WTO Agreement.

Adanya Permendag dan Permentan tentang Pembatasan Impor Hortikulura dan juga Pergub Jatim yang melarang impor buah khas Jatim masuk ke wilayah Jatim pada 1 bulan sebelum dan 2 bulan setelah panen raya ini jelas bertentangan dengan Perjanjian ACFTA yang memasukkan hortikultura kedalam produk normal yang mengikuti ketentuan perdagangan bebas yang bebas bea masuk dan tidak ada pembatasan kuota. Pertentangannya adalah Perjanjian ACFTA menerapkan prinsip WTO bahwa tidak ada perbedaan produk lokal dan produk impor, sedangkan pembatasan impor, sehingga bisa dikatakan bahwa ini bentuk konflik norma.

Pertentangan antara Perjanjian ACFTA dengan peraturan perudang-undangan nasional ini merupakan suatu hal yang mungkin terjadi. Suatu negara yang telah mengesahkan perjanjian internasional, dalam pelaksanaannya di wilayahnya maka akan berhadapan dengan hukum atau peraturan perundang-undangan nasional yang lain. ${ }^{19}$ Dalam menghadapi pertentangan antara hukum nasional dan internasional ini membuat negara mengalami dilema apakah akan mengutamakan penerapan perjanjian internasional dengan mengesampingkan hukum nasional atau sebaliknya. Apabila perjanjian internasional dikesampingkan dengan alasan bertentangan dengan hukum nasional atau peraturan perundangundangan nasional maka dikhawatirkan akan terjadi anarki internasional yang bisa merugikan semua pihak, sekaligus juga akan merendahkan nilai-nilai dan tujuan luhur dari perjanjian internasional. ${ }^{20}$

19 I Wayan Parthiana, Hukum Perjanjian Internasional (Bagian 2), Mandar Maju, Bandung, 2005, hlm. 275 276.

20 Ibid., hlm. 276. 
Dari uraian di atas maka disimpulkan bahwa sebaiknya tidak menjadikan hukum nasional sebagai alasan pembenar untuk mengesampingkan suatu perjanjian internasional ataupun menjadi alasan pembenar atas pelanggaran atau kegagalan dalam melaksanakan perjanjian internasional. ${ }^{21}$ Hal ini sesuai dengan Pasal 27 Konvensi Wina 1986 tentang Hukum Perjanjian Internasional yaitu "A party may not invoke the provisions of its national law as justification of its failure to perform a treaty", yang diartikan bahwa salah satu pihak tidak boleh menjadikan ketentuan dalam hukum nasionalnya sebagai pembenar atas kegagalannya dalam melaksanakan suatu perjanjian internasional.

Ketentuan Pasal 27 Konvensi Wina 1986 ini menjadi salah satu alasan bahwa adanya Permen dan Pergub yang membatasi impor hortikultura ini tidak bisa dibenarkan sebab justru menimbulkan pelanggaran pada perjanjian internasional yang meliberalisasikan perdagangan yaitu Perjanjian ACFTA atau perjanjian FTA yang lain dan perjanjian WTO.

Kekuatan mengikat ini didukung dengan pandangan bahwa perjanjian internasional digolongkan sebagai sumber hukum formal yang merupakan treaty contract yang artinya perjanjian internasional sebagaimana kontrak atau perjanjian perdata yang mengikat para pihak yang mengadakan perjanjian. ${ }^{22}$ Perjanjian ACFTA memenuhi ini sehingga walaupun pembuat perjanjian mengatasnamakan ASEAN tetapi negara anggotanya dapat dikatakan terikat perjanjian ini.

Negara-negara ketika membentuk suatu organisasi internasional didorong oleh satu tujuan atau objek yang sama, yaitu mereka menghendaki bahwa dalam suatu bidang tertentu mereka tidak usah lagi menjalankan sendiri dan bekerja sendirian akan tetapi diwakili oleh suatu badan (entity) yang tampil atas nama mereka. ${ }^{23}$ Alasan keterikatan ini adalah ASEAN sebagai sebuah institusi regional yang telah mengikat secara hukum karena ditandatanganinya ASEAN Charter, yang secara progresif melakukan liberalisasi perdagangan maupun penanaman modal. ${ }^{24}$

ASEAN Charter (Piagam ASEAN) ini ditandatangani tahun 2005 dan disahkan oleh Pemerintah Indonesia dengan UU No. 38 tahun 2008 Tentang Pengesahan Charter of The Association of Southeast Asian Nations. Piagam ASEAN ini berisikan garis besar haluan kebijakan ASEAN, yang menyebutkan bahwa ASEAN adalah satu kesatuan pasar bebas. ${ }^{25}$ Tercantum dalam Pasal 1 ayat (5) Piagam ASEAN.

\section{Ibid.}

22 T. May Rudy, Hukum Internasional 1, Refika Aditama, Bandung, 2006, hlm. 4.

23 T. May Rudy, Hukum Internasional 2, Refika Aditama, Bandung, 2009, hlm. 110.

24 Daeng, Jebakan ASEAN dalam Komitmen Ambisius 2010, Free Trade Watch: Mewujudkan Keadilan Ekonomi, Volume III, Oktober 2010, hlm. 117.

25 Daeng, Menyoal Pelanggaran Konstitusi dalam ACFTA, Free Trade Watch: Mewujudkan Keadilan Ekonomi, Volume I, April 2011, hlm. 5. 
Kedudukan perjanjian internasional dalam sistem hukum Indonesia secara hierarkis ada di atas Pergub karena perjanjian internasional ini ketika berlaku maka mengikat secara nasional, sedangkan Pergub sifatnya hanya regional. Untuk Permen tidak ada dalam tata urutan perundang-undangan sesuai dengan UU No. 12 Tahun 2011 tersebut. Untuk menentukan posisinya dibandingkan Perjanjian ACFTA dapat dianalogikan bahwa secara hirarkis Presiden di atas menteri maka Perpres di atas Permen, sedangkan Perjanjian internasional baik sesuai aliran Monisme maupun Dualisme posisinya di atas Perpres. Oleh karena itu dengan disahkan Perjanjian ACFTA dengan Keppres No. 48 Tahun 2004 yang telah diuraikan pada sub bab sebelumnya bahwa perjanjian ACFTA ini berlaku maka kedudukannya diakui pada sistem hukum nasional, sehingga adanya pertentangan dengan Permen dan Perda yang membatasi larangan buah impor untuk memutuskan mana yang lebih berlaku digunakan asas Lex Superior derogat lex inferiori. Dengan diterapkan asas ini maka ini menjadi alasan juga bahwa Perjanjian ACFTA dapat lebih diutamakan dibanding Permen dan Pergub yang bertetangan dengan perjanjian ini.

Tujuan adanya pergub dan permen sebagaimana dibahas di atas pada dasarnya adalah memberikan perlindungan hukum terhadap UMKM, tetapi pembuat kebijakan melupakan bahwa ada mekanisme perlindungan yang diatur dalam Artikel XIX GATT-WTO Agreement yang memuat tentang safeguard dari dampak perdagangan bebas, yaitu ancaman kerugian serius pada industri lokal. Oleh karena itu perlu dirumuskan perlindungan hukum terhadap UMKM yang ideal sehingga tidak bertentangan dengan perjanjian internasional yang telah disepakati Indonesia tetapi tetap dapat memberikan perlindungan dalam konteks hukum normatif yang maksimal untuk UMKM.

\section{B. Bentuk Perlindungan Hukum bagi UMKM Akibat Berlakunya Perjanjian ACFTA}

Sebelum adanya Perjanjian ACFTA UMKM sudah mendapat perlindungan dengan adanya Undang-undang No. 20 Tahun 2008 tentang Usaha Mikro, Kecil, dan Menengah. UU ini mengatur kriteria usaha yang dapat dikatakan sebagai Usaha Mikro, Kecil, dan Menengah, pemberdayaan dan pengembangan usaha, pembiayaan, kemitraan. Pengaturan mengenai hal-hal tersebut menunjukkan adanya perlindungan hukum terhadap UMKM. Perlindungan ini didukung dengan peraturan perundanganundangan lain yang lebih spesifik baik yang setara UU yaitu UU Perbankan, UU Pemerintah Daerah, UU Penanaman Modal dan UU Antimonopoli dan Persaingan Usaha Tidak Sehat atau aturan dibawahnya. UU perbankan memberikan perlindungan dalam hal permodalan, UU Pemerintah Daerah mengatur tentang salah satu urusan wajib yang menjadi kewenangan Pemda kabupaten/ kota adalah memfasilitasi pengembangan 
koperasi, dan UMKM. UU Penanaman modal tentang investasi baik dalam negeri maupun investasi asing untuk UMKM, dan UU Antimonopoli dan Persaingan Usaha Tidak sehat memberikan perlindungan dari dumping.

Banyak kendala yang membuat perlindungan UMKM yang sudah ada menjadi tidak masalah, hambatan ini bisa berasal dari peraturan perundang-undangan juga. Pembiayaan UMKM mensyaratkan adanya jaminan dan ini yang menjadikan kendala untuk UMKM mendapatkan modal. Seringkali UMKM tidak dapat memenuhi persayaratan untuk mendapatkan bantuan modal demi mempertahankan usahanya. Sering kali didapati, UMKM Indonesia tidak memiliki laporan keuangan yang sistematis, banyak juga yang tidak ada laporan keuangannya. Hal ini menyulitkan perbankan untuk mempertimbangkan pemberian kredit. Biasanya bank akan menolak kredit yang diajukan UMKM yang tidak memilikilaporan keuangan. ${ }^{26}$

Bank-bank di Indonesia enggan memberikankredityangjustrudibutuhkan oleh para pelaku usaha untuk menggerakkan roda ekonomi. Bank enggan menyalurkan pada industri tetapi justru untuk sektor konsumsi dan properti dengan alasan resikonya lebih kecil dan pengembaliannya lebih cepat. Pinjaman untuk sektor UMKM sangat tinggi bunganya, kondisi ini menyebabkan deindustrialisasi yang dampaknya sangat berbahaya, karena deindustrialisasi meningkatkan jumlah pengangguran di Indonesia yang berdampak buruk pada kehidupan sosial dan politik serta mengganggu kestabilan makroekonomi. ${ }^{27}$

Perlindungan hukum UMKM dari dampak berlakunya perjanjian ACFTA ini sebenarnya secara umum sudah diatur pula dalam Pasal 3 ayat (8) huruf f Perjanjian ACFTA yang menyebutkan bahwa pengamanan perdagangan dari dampak adanya perjanjian ini adalah mengikuti ketentuan WTO, yang tentu saja Artikel XIX GATT-WTO Agreement. Selain itu adanya perjanjian ACFTA sudah didukung dengan perlindungan hukum yang mengikuti yaitu penurunan tariff dengan kategori produk sensitif yang jangka waktu dan besar penurunannya berbeda dari EHP dan produk normal. ${ }^{28}$

Produk-produk dalam kelompok Sensitive, akan dilakukan penurunan tarif mulai tahun 2012, dengan penjadwalan bahwa maksimun tariff bea masuk pada tahun 2012 adalah $20 \%$ dan akan menjadi 0-5\% mulai tahun 2018. Produk sensitif ini antara lain: (1) barang jadi kulit yaitu tas, dompet; (2) Alas kaki yaitu sepatu sport, casual, kulit; (3) Kacamata;

26 Surabaya Pagi, 18 Februari 2011, Masalah yang Dihadapi dalam Pemberian Kredit Perbankan, hlm. 19 kolom 2-3.

27 Afifah Kusumadara, The Role of Law in Indonesian Economic Development, http://karyatulishukum. files.wordpress.com/2011/06/secured-kedudukan-hukum-sbg-alat- pembangunan-ekonomi.pdf, diakses 1 Maret 2013 pukul 13.00 WIB, hlm. 18-21.

28 Tahapan penurunan tariff ini diatur dalam Departemen Perdagangan Ditjen KPI, Program Penurunan Tarif Bea Masuk, http://www.ditjenkpi.go.id, diakses 13 Maret 2013 pukul 13.00 WIB. 
(4) Alat Musik yaitu tiup, petik, gesek; (5) Mainan misalnya Boneka; (6) Alat Olah Raga; (7) Alat Tulis; (8) Besi dan Baja;

(9) Spare part; (10) Alat angkut; (11) Glokasida dan Alkaloid Nabati; (12) Senyawa Organik; (13) Antibiotik; (14) Kaca; (15) Barang-barang Plastik. ${ }^{29}$ Produk nomor 1-7 rata-rata merupakan industri padat karya yang dijalankan oleh UMKM.

Indonesia memiliki PP No. 34 Tahun 2011 Tentang Tindakan Anti Dumping, Tindakan Imbalan dan Tindakan Pengamanan Perdagangan, tetapi belum secara detail mengatur sebagaimana Artikel XIX GATT-WTO Agreement, sehingga perlu adanya UU khusus yang memberikan perlindungan hukum terhadap industri lokal termasuk di dalamnya UMKM dalam bentuk UU dan disesuaikan ketentuan WTO dan kepentingan nasional. Untuk memberikan perlindungan yang berbentuk peraturan perundang-undangan nasional berupa produk hukum diperlukan peran pemerintah.

Pasal 5 ayat (2) Piagam ASEAN menyebutkan Negara-Negara Anggota wajib mengambil langkah-langkah yang diperlukan, termasuk pembuatan legislasi dalam negeri yang sesuai, guna melaksanakan ketentuanketentuan dalam Piagam ini secara efektif, dan mematuhi kewajiban-kewajiban keanggotaan. Pelaksanaan ASEAN Charter digantungkan pada masing-masing negara anggota ASEAN sesuai amanat, maka Pemerintah Indonesia perlu membuat aturan pelaksanaan yang sesuai kepentingan nasional berdasarkan UUD $1945 .{ }^{30}$ Berdasarkan pasal ini maka sebenarnya Indonesia dapat membuat peraturan nasional sendiri sebagai pelaksanaan perjanjian internasional yang telah disetujui ASEAN termasuk Perjanjian ACFTA, sehingga peraturan yang dibuat disesuaikan dengan kepentingan dan kondisi nasional tetapi tidak bertentangan dengan perjanjian internasional yang telah disepakati termasuk dalam hal perlindungan kepada industri lokal termasuk UMKM di dalamnya.

Langkah perlindungan lain yang dapat ditempuh adalah kebijakan internal yang tidak ada kaitannya dengan perjanjian internasional atau hubungan dengan negara lain tetapi tetap dapat membantu memberikan perlindungan hukum pada UMKM akibat adanya perjanjian ACFTA ini dalam bentuk lain misalnya permodalan, sebab modal salah satu pendukung untuk dapat bersaing. Untuk itu diperlukan adanya peraturan perundangundangan yang mengatur pemberian kredit/ pembiayaan UMKM yang berkepastian hukum.

Sampai saat ini belum ada hukum nasional yang dapat mengakomodasi dan menjembatani perbedaan kepentingan ini

29 Diatur dalam Peraturan Menteri Keuangan (PMK) Nomor 117/PMK.011/2012 tentang Penetapan Tarif Bea Masuk Dalam Rangka ACFTA.

30 Hukum Online, Pengujian UU Ratifikasi Piagam ASEAN Kandas, http://www.hukumonline.com/berita/ baca/lt512cb1408c03e/pengujian-uu-ratifikasi-piagam- asean-kandas, diakses 26 Maret 2013 pukul 13.00 WIB. 
antara UMKM dan pihak perbankan, sehingga UMKM masih saja kesulitan mendapatkan modal, maka bagaimana dapat bersaing dengan produsen dari China. Oleh karena itu perlu perundang-undangan nasional memberikan kemudahan kredit permodalan kepada UKM dengan bunga ringan dan persyaratan perizinan yang mudah sehingga biaya produksi turun maka harga jual akan bersaing dengan produk China.

Selain kebijakan permodalan, perlindungan hukum lain yang dapat ditempuh adalah dengan penerapan standarisasi nasional barang impor, sehingga SNI tidak hanya lagi menjadi hiasan yang jika tidak dipenuhi tidak ada konsekuensi hukumnya. Standar dalam perdagangan internasional sudah menjadi prasyarat agar suatu produk dapat berkompetisi di pasar global. Negara pengimpor dan konsumen berharap produk yang masuk ke pasar di dalam negerinya dan produk yang digunakan konsumen adalah produk yang berstandar. Untuk negara, produk yang berstandar menyangkut kepentingan umum atau kepentingan publik. Pasalnya, produk itu akan digunakan oleh masyarakatnya. Pemerintah berkewajiban menjaga agar produk yang digunakan atau dikonsumsi penduduknya bebas dari bahaya bagi keselamatan atau kesehatan penduduknya. ${ }^{31}$
Penggunaan SNI secara alamiah memang dapat berdampak terhadap pembatasan perdagangan produk, yang bertujuan untuk memastikan bahwa setiap negara memiliki hak kedaulatan untuk menyediakan perlindungan yang maksimal. ${ }^{32}$ Dengan diterapkan SNI secara ketat maka tidak ada produk China khususnya yang berbahaya bagi konsumen dan UMKM juga tidak dirugikan akibat kalah bersaing dengan produk impor dari China yang lebih murah tetapi berbahaya.

Terdapat dua faktor terpuruknya UMKM yaitu internal yang disebabkan dari dalam internal UMKM itu sendiri dan juga faktor eksternal UMKM baik dari dalam negeri maupun luar negeri. Untuk penghambat dari dalam negeri, salah satunya adalah kurangnya persiapan Pemerintah dalam menghadapi kesepakatan-kesepakatan liberalisasi perdagangan termasuk ACFTA. Sedangkan faktor dari luar negeri salah satunya adalah tidak terbendungnya produk China dengan harga murah, bisa jadi ini salah satu bentuk dumping. ${ }^{33}$

Teori perdagangan bebas juga menyebutkan bahwa melindungi produsen dalam negeri terhadap "dumping” (dumping berkanaan dengan menjual di pasar luar negeri dengan harga yang lebih rendah dari harga yang dikenakan di dalam negeri), merupakan hal yang diperbolehkan dalam memberikan proteksi perdagangan. ${ }^{34}$

31 Adolf, Huala, Labelisasi Standar dalam Menyikapi ACFTA, http://korantempo.com/korantempo/ koran/2010/10/01/Opini/krn.20101001.213309, diakses 12 Maret 2013 pukul 13.00 WIB.

32 Indah Suksmaningsih, Kaidah Internasional dalam Hukum Indonesia: Peluang yang Tidak Dimanfaatkan, Global Justice Update, Tahun ke 7, Edisi 4, Desember 2009, hlm. 101.

33 Ina Primiana, Menggerakkan Sektor Riil UKM dan Industri, Alfabeta, Bandung, 2009, hlm. 115-116.

34 Dominick Salvatore, Ekonomi Internasional, Erlangga, Jakarta, 1995, hlm. 108. 
Dumping ini baik terbukti atau tidak dapat memberikan dampak yang sangat besar terhadap laju pertumbuhan industri produk yang bersangkutan. Tidak adanya ketentuan anti dumping yang menyeluruh seperti halnya negara lain misalnya Uni Eropa dan AS maka bagi Indonesia timbul kesulitan untuk mengadakan tuduhan kepada negara lain yang melakukan dumping ke Indonesia. ${ }^{35}$ Sudah ada PP anti dumping tetapi ini dinilai belum membahas secara komprhensif sebagaimana Uni Eropa dan AS. Pembatasan tindakan bisnis supaya tidak mengarah pada praktek dumping sebaiknya diatur dalam suatu UU yang secara eksplisit memasukkan berbagai tindakan sebagai perbuatan yang dilarang termasuk dumping. ${ }^{36}$

Pada kasus dumping yang pernah dilakukan Korsel dan Taiwan atas serat polister Indonesia, Asosiasi Poliester Indonesia (API) menyampaikan keberatan kepada Dirjen Perdagangan Dalam Negeri, dan cara penyelesaian kasusnya melalui jalur Kadin masing-masing negara. ${ }^{37}$

Pengalaman tersebut menandakan bahwa pengaturan dumping yang bersifat parsial tidak dapat menyelesaikan masalah secara tuntas. Sebenarnya kasus ini dapat diselesaikan melalui jalur sebagaimana yang dilakukan oleh negara lain yang mempunyai ketentuan antidumping yang didasarkan pada ketentuan GATT-WTO Agreement yang dituangkan dalam UU Nasional. ${ }^{38}$

Berdasarkan uraian di atas tampak bahwa peraturan perundang-undangan yang ada belum representatif melindungi UMKM dan belum terpenuhi unsur kepastian hukum sehingga perlindungan hukum yang diberikan terhadap UMKM belum maksimal. Oleh karena itu diperlukan peran aktif pemerintah diharapkan dapat mewujudkan hukum yang representatif dalam pembangunan ekonomi yaitu hukum yang berkepastian sehingga dapat memberikan perlindungan hukum preventif maupun represif yang secara substansi memerlukan peran aktif pemerintah.

Azas-asas utama dari hukum ekonomi yang meliputi 3 hal yaitu (1) asas keseimbangan kepentingan, (2) asas pengawasan publik, dan (3) asas campur tangan Negara terhadap kegiatan ekonomi. ${ }^{39}$ Azas ini didukung oleh John Maynard Keynes yang menyatakan sebuah keharusan campur tangan atau intervensi Negara melalui kebijakan fiskal dan moneter. ${ }^{40}$ Syarat utama untuk menjamin sistem ekonomi yang fair untuk pengusaha besar maupun pengusaha kecil dan masyarakat pada umumnya adalah

35 Sukarmi, Regulasi Anti di Bawah Bayang-Bayang Pasar Bebas, Sinar Grafika, Jakarta, 2002, hlm. 5.

36 Ibid., hlm. 6.

37 Ibid.

38 Ibid.

39 Sri Rejeki Hartono, Hukum Ekonomi Indonesia, Bayumedia, Malang, 2007, hlm. 13.

40 Johnny Ibrahim, Pendekatan Ekonomi Terhadap Hukum: Teori dan Implikasi Penerapannya dalam Penegakan Hukum, Putra Media Nusantara \& ITS Press, Surabaya, 2009, hlm. 27. 
perlu adanya peran pemerintah yang sangat canggih yang merupakan kombinasi dari prinsip non intervention dalam bisnis individu dan prinsip campur tangan pemerintah dalam bentuk pembentukan hukum yang mengatur sistem ekonomi. ${ }^{41}$ Peran pemerintah sebagaimana diuraikan di atas menurut Adam Smith merupakan bentuk intervensi. ${ }^{42}$

Dalam teori perdagangan bebas, proteksi perdagangan diperbolehkan dengan beberapa alasan, salah satunya mendorong industri-industri dalam negeri agar mapan dan tumbuh hingga efisien the infantindustry agreement)..$^{43}$ Infant industry yang dimaksud dalam teori ini adalah UMKM, maka berdasarkan teori ini sudah menjadi kewajiban Pemerintah Indonesia untuk memberikan perlindungan terhadap UMKM. Yang pertama kali dapat dilakukan adalah dengan membuat hukum yang berkepastian. Hal ini sejalan dengan pemikiran Adam Smith bahwa hukum tidak dapat dipisahkan dari anasir ekonomi ${ }^{44}$.

Dalam membentuk perlindungan hukum ideal terhadap UMKM dari dampak adanya Perjanjian ACFTA, pemerintah perlu memperhatikan asas-asas pembentukan peraturan perundang-undangan yang baik dan 5 syarat hukum yang kondusif untuk pembangunan ekonomi yaitu pertama adalah stability bahwa hukum menjaga keseimbangan dan berlaku sama di hadapan kepentingan-kepentingan yang saling bertentangan. Yang kedua predictability yaitu akibat suatu hukum dapat diprediksi ke depannya. Hal ini penting bagi semua pelaku ekonomi. Yang ketiga fairness atau yang dapat disamakan dengan keadilan yaitu persamaan di depan hukum dan standar sikap pemerintah diperlukan untuk memelihara mekanisme pasar dan mencegah birokrasi yang berlebihan, adil untuk semua pihak dalam pembangunan ekonomi. Yang keempat adalah educative artinya bermuatan pendidikan. Dan yang kelima atau terakhir adalah transparency sehingga aturan hukum dapat diketahui oleh seluruh pihak, berlaku sama bagi semua pihak dan dapat diramalkan akibat hukumnya. ${ }^{45}$

Perlindungan hukum ideal ini diharapkan dapat memberikan perlindungan preventif supaya tidak terjadi hal yang dapat merugikan UMKM kaitannya dengan adanya Perjanjian ACFTA sebagaimana fokus kajian tesis ini. Hukum yang kondusif untuk pembangunan ekonomi salah satunya adalah predictable yaitu dapat memprediksi dampak kedepannya sehingga sebaiknya juga dapat merumuskan perlindungan hukum represif dengan adanya mekanisme penyelesaian masalah

41 A. Sonny Keraf, Etika Bisnis: Tuntutan dan Relevansinya, Kanisius, Yogyakarta, 1998, hlm. 226.

42 Mikhael Dua, Filsafat Ekonomi: Upaya Mencari Kesejahteraan Bersama, Kanisius, Yogyakarta, 2008, hlm. 54

43 Dominick Salvatore, Op.cit., hlm. 108.

44 Jonker Sihombing, Peran dan Aspek Hukum dalam Pembangunan Ekonomi, Alumni, Bandung, 2000, hlm. 3.

45 Ibid., hlm. 2. 
atau sengketa dari yang timbul dari adanya Perjanjian ACFTA.

Sedangkan bentuk perlindungan hukum yang ideal terhadap UMKM dari dampak berlakunya perjanjian ACFTA adalah pertama safeguard adalah poin pentingdalam perlindungan hukum industri lokal termasuk UMKM sehingga sebaiknya artikel XIX GATT-WTO Agreement ini ditransformasikan pada sebuah UU sebagai payung hukum atas perlindungan kepada industri lokal. Kedua yaitu Perbaikan regulasi pemberiaan kredit/ pembiayaan terhadap industri lokal, termasuk UMKM di dalamnya, sehingga ada dukungan secara hukum juga untuk bersaing pada era perdagangan bebas akibat Indonesia menjadi anggota WTO atau karena keikutsertaan Indonesia dalam beberapa perjanjian FTA. Ketiga adalah adanya koreksi atas perda atau permen yang bertujuan memberikan proteksi terhadap industri lokal secara umum maupun UMKM yang bertentangan dengan perjanjian internasional termasuk ACFTA. Hal ini bertujuan untuk mencegah adanya peraturan proteksi yang bertentangan dengan perjanjian internasional lagi sebab ada model proteksi sesuai artikel XIX GATT-WTO Agreement.

\section{Simpulan}

Perjanjian ACFTA berlaku dalam sistem hukum Indonesia karena beberapa alasan yaitu perjanjian ini sudah melalui 3 tahapan yaitu perundingan, penandatanganan dan pengesahan, dan meskipun dalam Keppres pengesahannya hanya menjadikan Perjanjian
ACFTA ini lampiran yang dinyatakan tidak dapat dipisahkan dan dianggap transformasi setengah hati atau pengakuan inkorporasi yang sembunyi-sembunyi tetapi tetap bisa dianggap berlaku karena memang kenyataannya Indonesia mengikuti transformasi, inkorporasi sekaligus. Berkaitan dengan terjadi konflik hukum dengan peraturan perundang-undangan yang melindungi UMIM maka kedudukan Perjanjian ACFTA ini lebih diutamakan dengan beberapa alasan, yaitu pertama sesuai dengan Pasal 27 Konvensi Wina 1986 dinyatakan perundang-undangan nasional tidak boleh dijadikan alasan pembenar atas pelanggaran, kegagalan perjanjian internasional dan/atau mengesampingkan perjanjian internasional. Kedua Perjanjian ACFTA ini menjadi hukum organisasi internasional yang wajib ditaati oleh anggotanya karena dalam perundingan Perjanjian ACFTA, ASEAN tampil atas nama negara anggota ASEAN, sehingga walaupun ada perundang-undangan nasional yang bertentangan maka Perjanjian ACFTA secara normatif harus didahulukan.

Perlindungan hukum nasional terhadap UMKM sudah ada sebelum Perjanjian ACFTA berlaku, diatur secara khusus dengan UU No. No. 20 Tahun 2008 Tentang Usaha Mikro, Kecil, dan Menengah yaitu dalam hal pemberdayaan dan pengembangan usaha, pembiayaan dan kemitraan. Perlindungan hukum atas UMKM dalam ketiga hal tersebut didukung oleh UU Perbankan, UU Pemerintah Daerah, UU Penanaman 
Modal dan UU Antimonopoli dan Persaingan Usaha Tidak Sehat. Adanya perjanjian ACFTA sudah didukung dengan perlindungan hukum yang mengikuti yaitu penurunan tariff dengan kategori produk sensitif yang jangka waktu dan besar penurunannya berbeda dari EHP dan produk normal, selain itu safeguard dari berlakunya Perjanjian ACFTA ini juga mengikuti Artikel XXIX GATT-WTO Agreement. Perlindungan hukum yang ada belum dapat memberikan perlindungan yang maksimal terbukti dampak
Perjanjian ACFTA ini merugikan UMKM, hal ini dikarenakan tidak adanya kepastian hukum terbukti ada perundang-undangan nasional yang berbenturan dengan Perjanjian ACFTA. Inti dari perlindungan hukum yang ideal adalah kepastian hukum dan tidak bisa lepas dari campur tangan pemerintah. Untuk mewujudkan perlindungan hukum yang ideal diperlukan sebuah hukum yang kondusif untuk pembangunan ekonomi yang memenuhi 5 syarat yaitu stable, predictable, fair, educative, dan transparent.

\section{DAFTAR PUSTAKA}

\section{Buku}

A. Sonny Keraf, 1998, Etika Bisnis: Tuntutan dan Relevansinya, Kanisius, Yogyakarta.

Ana Mercedes Lopez Rodriguez, 2002,

Lex Mercatoria, School of Law, Departement of Private Law University of Aarhus.

Damos Dumoli Agusman, 2010, Hukum Perjanjian Internasional (Kajian Teori dan Praktik Indonesia), Refika Aditama, Bandung.

Dominick Salvatore, 1995, Ekonomi

Internasional, Erlangga, Jakarta.

I Wayan Parthiana, 2002, Hukum Perjanjian

Internasional (Bagian 1), Mandar Maju, Bandung. 2005 , Hukum Perjanjian Internasional (Bagian 2), Mandar Maju, Bandung.
Ina Primiana, 2009, Menggerakkan Sektor

Riil UKM dan Industri, Alfabeta, Bandung.

Johnny Ibrahim, 2009, Pendekatan Ekonomi Terhadap Hukum: Teori dan Implikasi Penerapannya dalam Penegakan Hukum, Putra Media Nusantara \& ITS Press, Surabaya.

Jonker Sihombing, 2000, Peran dan Aspek Hukum dalam Pembangunan Ekonomi, Alumni, Bandung.

Mansour Fakih, 2001, Runtuhnya Teori Pembangunan dan Globalisasi, Pustaka Pelajar, Yogyakarta.

Mikhael Dua, 2008, Filsafat Ekonomi: Upaya Mencari Kesejahteraan Bersama, Kanisius, Yogyakarta.

Mohammad Sood, 2011, Hukum Perdagangan Internasional, RajaGrafindo Persada, Jakarta. 
Sri Rejeki Hartono, 2007, Hukum Ekonomi

Indonesia, Bayumedia, Malang.

Sukarmi, 2002, Regulasi Anti di

Bawah Bayang-Bayang Pasar Bebas,

Sinar Grafika, Jakarta.

T. May Rudy, 2006, Hukum Internasional 1,

Refika Aditama, Bandung, 2006.

,2009, Hukum Internasional 2, Refika Aditama, Bandung, 2009.

\section{Jurnal}

Daeng, dkk, Menggugat Perjanjian

Kerjasama ASEAN-China, Global

Justice Update Tahun 7, Edisi 4, Desember 2009.

Daeng, Jebakan ASEAN dalam Komitmen

Ambisius 2010, Free Trade Watch:

Mewujudkan Keadilan Ekonomi,

Volume III, Oktober 2010.

Daeng, Menyoal Pelanggaran Konstitusi dalam ACFTA, Free Trade Watch: Mewujudkan Keadilan Ekonomi, Volume I, April 2011.

Indah Suksmaningsih, Kaidah Internasional dalam Hukum Indonesia: Peluang yang Tidak Dimanfaatkan, Global Justice Update, Tahun 7, Edisi 4, Desember 2009.

\section{Peraturan Perundang-undangan}

Framework Agreement On Comprehensive Economic Co-Operation Between The Association Of South East Asian Nations And The People's Republic Of China.
General Agreement on Tariffs and TradeWorld Trade organizaton.

Kovensi Wina 1986.

Undang-undang Republik Indonesia Nomor 10 Tahun 1998 tentang Perubahan Atas Undang-Undang No. 7 Tahun 1992 Tentang Perbankan.

Undang-undang Republik Indonesia Nomor 5 Tahun 1999 tentang Anti Monopoli dan Persaingan Usaha Tidak Sehat.

Undang-undang Republik Indonesia Nomor 24 Tahun 2000 tentang Perjanjian Internasional

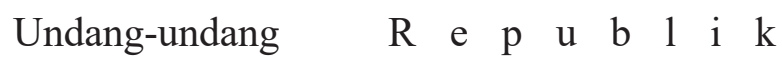
Indonesia Nomor 34 Tahun 2004 tentang Pemerintahan Daerah.

Undang-undang Republik Indonesia Nomor 25 Tahun 2007 tentang Penanaman Modal.

Undang-undang Republik Indonesia Nomor 20 Tahun 2008 tentang Usaha Mikro, Kecil, dan Menengah.

Peraturan Menteri Keuangan (PMK) Nomor 117/PMK.011/2012 tentang Penetapan Tarif Bea Masuk Dalam Rangka ACFTA.

Piagam ASEAN.

\section{Surat Kabar}

Surabaya Pagi, 28 Januari 2010, ACFTA Ancam Empat Industri Padat Karya. Surabaya Pagi, 18 Februari 2011, Masalah yang Dihadapi dalam Pemberian Kredit Perbankan. 


\section{Naskah Internet}

Mohd. BurhanTsani, Status $\mathbf{H} \quad \mathbf{u} \quad \mathbf{k} \quad \mathbf{u} \quad \mathbf{m}$ Internasional dan $P$ e r j a $\mathbf{n} \mathbf{j} \mathbf{i}$ a $n$ Internasional dalam Hukum Nasional Republik Indonesia (dalam prespektif Hukum Tata

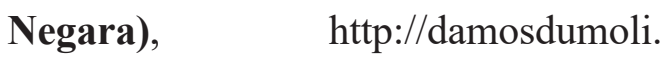
blogspot.com/2009/03/status-hukuminternasional-dan_12.html.

Wikipedia, Perdagangan, http://id.wikipedia. org/wiki/Perdagangan.

Amrie Hakim, Dasar Hukum Pemberlakuan ACFTA, http://www.hukumonline. com/klinik/detail/ 1t4b04bef2aa8ee/ dasar-hukum-pemberlakuan-acfta.

Ibnu Purna, dkk, ACFTA sebagai Tantangan Menuju Perekonomian yang Kompetitif, http://www.setneg. go.id/index.php?option=comcontent\&t ask=view\&id $=437 \quad 5 \&$ Itemid $=29$.

Abdul Rosid, Modul Manajemen UKM: UKM di Indonesia dan Peranan UKM, pksm.mercubuana.ac.id/new/.../ files.../31013-3-478126269633.doc.

World Trade Organization, Trading into the Future: Introduction to the WTO. Beyond the Agreements.
Regionalism-Friends or Rivals?, http://www.wto.org/english/ thewto_e/ whatis_e.

Fatkhurrohman Taufiq, Jawa Timur Larang Impor Hortikultura, http:// w w w. t e m p o.co/r e a d / news/2012/03/02/180387611/JawaTimur-Larang-Impor-Hortikultura.

Afifah Kusumadara, The Role of Law in Indonesian Economic Development, http://karyatulishukum.files.wordpress. com/2011/06/secured-kedudukanhukum-sbg-alat-pembangunanekonomi.pdf.

Departemen Perdagangan Ditjen KPI, Program Penurunan Tarif Bea Masuk, http://www.ditjenkpi.go.id.

Hukum Online, Pengujian UU Ratifikasi Piagam ASEAN Kandas, http:// www.hukumonline.com/berita/baca/ 1 t5 $12 \mathrm{cb} 1408 \mathrm{c} 03 \mathrm{e} / \mathrm{pengujian-uu-}$ ratifikasi-piagam-asean-kandas.

Adolf,Huala, Labelisasi Standar dalam MenyikapiACFTA, http://korantempo. com/korantempo/koran/2010/10/01/ Opini/krn.20101001. 213309. 